Diabetologia 6, 519-523 (1970)

\title{
Effects of Oral Contraceptives on Carbohydrate Metabolism
}

\author{
A. Vermedlen, R. Daneels and M. Thiery \\ Dept. of Endocrinology and Metabolism and Dept. of Obstetrics and Gynecology, Akademisch Ziekenhuis, \\ State University, Ghent, Belgium \\ Received: December 9, 1969
}

Summary. The authors studied the influence on insulin secretion and carbohydrate metabolism of 3 contraceptives, respectively of the conventional combined type (Planovin ${ }^{\circledR}$ ), of the sequential type (ORF $1658 \mathrm{~K}$ ) and of the luteal supplementation type (chlormadinone $0.5 \mathrm{mg} /$ day). All subjects were treated for $12-16$ months. Influence on insulin secretion and glucose metabolism was studied during an intravenous glucose tolerance test (IVGTT). Blood sugar levels were not influenced by any of the contraceptive drugs, and although slightly decreased during sequential and chlormadinone treatment, glucose disappearance rate $(K)$ did not show any statistically significant difference from pretreatment values. - Both fasting and post IVGTT insulin levels were increased after treatment with any of the 3 drugs tested, the difference from pretreatment levels being most pronounced with chlormadinone, and least with Planovin. The mechanism of the so-called "insulin resistance" in. duced by the contraceptives is discussed. It is concluded that not only the type of oral contraception used, but both the type and quantity of both the oestrogen and the progestogen determine the eventual influence of oral contraception on carbohydrate metabolism.

Effets des contraceptifs oraux sur le métabolisme des hydrates de carbone.

Résumé. Les auteurs ont étudié l'influence de 3 régimes différents de contraceptifs oraux (régime combiné: Planovin; régime séquentiel: ORF $1658 K$ et supplémentation lutéale: chlormadinone $0.5 \mathrm{mg}$ /jour) sur l'assimilati on du glucose $(K)$ et l'insulinémie. - Tous les sujets ont été traités pendant 12 à 16 mois, et l'influence sur l'insulinémie et l'assimilation du glucose ont été étudiés après surcharge intraveineuse rapide de glucose à la dose de $0.33 \mathrm{~g} / \mathrm{kg}$. - Ni la glycémie à jeun, ni les glycémies pendant l'épreuve d'hyperglycémie intraveineuse ne sont influencées par le traitement et quoique légèrement di. minué pendant le régime séquentiel (ORF $1658 \mathrm{~K}$ ) et la supplémentation lutéale, le coéfficient d'assimilation du glucose $(K)$ n'est pas modifié de manière statistiquement significative. - L'insulinémie à jeun et pendant l'épreuve d'hyperglycémie intraveineuse était significativement plus élevée pendant le traitement anticonceptionnel qu'avant et ce avec les trois régimes anticonceptionnels étudiés, mais la différence était la plus importante pendant la supplémentation lutéale (Chlormadinone) et la moins importante pendant le régime combiné (Planovin). Les mécanismes physiopathologiques de cette résistance à l'insuline due aux contraceptif́s sont discutés. - Il ressort de cette étude et d'une revue de la littérature, que les altérations $\mathrm{du}$ métabolisme glucidique observés pendant le traitement par les contraceptifs oraux sont déterminées non pas seulement par le type de regime de traitement mais par le type et la quantité d'oestrogènes et progestagène utilisés.

Auswirkungen von oralen Aniikonzeptiva auf den Kohlenhydratstoffwechsel.

Zusammenfassung: Die Autoren untersuchten die Beeinflussung der Insulinsekretion und des Kohlenhydratstoffwechsels durch 3 Ovulationshemmer (Planovin ${ }^{\circledR}$ vom konventionellen Kombinationstyp, ORF $1658 \mathrm{~K}$ vom Sequentialtyp, Chlormadinon $0,5 \mathrm{mg} / \mathrm{Tag}$ vom Progesteron-Ergänzungstyp). Alle Probandinnen wurden über 12-16 Monate behandelt. Die Einflüsse auf die Insulinsekretion und den Kohlenhydratstoffwechsel wurden während eines intravenösen GTT untersucht. Die Blutzuckerspiegel wurden durch die Ovulationshemmer nicht beeinflußt und auch die $k$-Werte zeigten trotz eines leich. ten Abfalls unter der Sequential- und der Chlormadionbehandlung keine statistisch signifikante Abweichung von den Ausgangswerten.

Die Insulinspiegel im Nüchternzustand und nach Glueosegabe stiegen nach Behandlung mit jeder der $\mathbf{3}$ Prüfsubstanzen an und zwar am stärksten unter Chlormadinon und am wenigsten unter Planovin. Der Mechanismus der durch die Anticonceptiva ausgelösten sog. „Insulinresistenz" wird diskutiert. Als Schlußfolgerung wird herausgestellt, daß nicht der Typ der oralen Konzeptionsverhütung selbst, sondern Art und Menge der verwandten Oestrogen- und Progesteronabkömmlinge für den möglichen Einfluß einer Antikonzeptions-Behandlung auf den Kohlenhydratstoffwechsel entscheidend sind.

Key-words: Oral contraceptives, glucose tolerance, chlormadinone, Planovin ${ }^{\circledR}$, plasma insulin, intravenous glucose tolerance.
Since the introduction of anti-ovulatory drugs for fertility control, several papers have been published concerning their influence on carbohydrate metabolism.

Since Waine et al. reported in 1963 that the use of oral contraceptives is frequently associated with decreased glucose tolerance, several authors have reported either elevated fasting blood sugar (FBS) levels, or abnormal results in oral (OGTT) intravenous and corticoid-stimulated glucose tolerance tests, with increased plasma insulin levels (see Spellacy [15] for review).

Whether the effeet is due to the oestrogen or the progestogen component and whether there exists a structure-activity relationship is not clear for the moment, although it is generally assumed that the oestrogen component, is the major factor responsible for the alteration in carbohydrate metabolism [9].

Since contraceptive pills, containing only progestogens, have recently become commercially available, we have been interested in the effects on carbohydrate metabolism of an oral contraceptive containing this component exclusively, and have compared its effects with those seen after treatment with a combination type and a sequential type oral contraceptive. 


\section{Material and Methods}

All women were within $10 \%$ of the ideal body weight [13] and were taking no other medications. None of them had a family history of diabetes.

I.V. glucose tolerance tests were performed at 8.30 a.m. Prior to the injection of glucose a venous blood sample was drawn for the determination of fasting blood glucose and insulin levels. Subsequently, $0.66 \mathrm{ml}$ of a $50 \%$ glucose solution per kilogram of body weight was injected rapidly. A stopwatch was started immediately and venous blood samples obtained exactly after $3,7,10,15,30,45,60$ and $90 \mathrm{~min}$. Blood glucose was determined by "Auto-analyser", using the O-toluidine Dubowski [7] method.

Blood samples for the determination of serum insulin were immediately centrifuged and the serum stored at $-20^{\circ} \mathrm{C}$.

Samples were analysed in duplicate by the radioimmunoassay method of Yalow and Berson [24].

The intravenous glucose test was analysed according to the method of Conard [5] using glucose levels between 10 and $60 \mathrm{~min}$, and the results expressed by the glucose disappearance rate. The latter is calculated according to the following equation: $K=$ $\frac{0.693}{\mathrm{~T} / 2} \times 100$ in which $\mathrm{T} / 2$ represents the biological half time expressed in minutes.

Intravenous GTT and insulin levels were determined both before and after $12-16$ months of treatment with an oral contraceptive. The effects on carbohydrate metabolism were evaluated by means of statistical analysis (Student's $t$ test) of the absolute changes in paired samples of blood glucose, $K$ values, serum insulin and insulin/glucose ratios. Three groups of subjects were studied. All received an oral contraceptive for 12-16 months.

The first group $(n=15)$ was treated uninterruptedly with a daily dose of chlormadinone acetate $0.5 \mathrm{mg}$ (luteal supplementation method).

To subjects of the second group $(n=15)$ Planovin (ethinyloestradiol $50 \mu \mathrm{g}+$ megestrolacetate $4 \mathrm{mg}^{1}$ ) was administered for 21 consecutive days in each 28 -days treatment cycle.

In the third group $(n=17)$ a sequential method of oral contraception was used: Mestranol $100 \mu \mathrm{g}$ per day (starting the 5 th day of cycle) was administered alone for 14 days, followed by the addition of $2 \mathrm{mg}$ 17 hydroxy-1 $\alpha$-methyl-pregn-4-ene-20-one acetate (Anagestonacetate) (ORF $1658 \mathrm{~K}^{2}$ ) to the estrogen for the next 7 days. In this group the tests were performed between the 20 th and 25 th day of the treatment cycle.

\section{Results}

None of the oral contraceptives studied had any statistically significant influence on the FBS level, nor

117 hydroxy-6-methylpregna-4,6-diene-3,20-dione acetate.

2 Ortho Research Found., Rariton (N.J.) (U.S.A.) on the glucose levels obtained during the IVGTT. This is shown in Table 1 for chlormadinone, but because of lack of significant differences, glucose levels have been omitted from Tables 2 and 3 . The $K$ value during chlormadinone treatment was slightly but not significantly decreased in comparison with the pretreatment value (Table 1); a decrease of borderline significance $(P=0.05)$ was observed during sequential treatment (Table 3) and essentially no change in $K$ value was observed during the Planovin treatment (Table 2).

Both the fasting and post-IVGTT insulin levels were significantly increased after treatment for more than one year with any of the three drugs tested. When the total insulin secretion $(\Sigma \mathrm{I})$, i.e. the sum total of the insulin levels obtained at $3,7,10,15,30$, 45, 60 and $90 \mathrm{~min}$, was compared, a significant increase was again observed following treatment with any of the three contraceptives. Insulin/glucose ratios, however, show a significant increase only after treatment with chlormadinone. With a sequential regimen the increase in these ratios was of borderline significance whereas, except for fasting ratio's, no significance was found after Planovin ${ }^{\circledR}$ treatment.

\section{Discussion}

It is the consensus that oestrogens, and mainly mestranol, $[1,6,10]$ may cause alterations in carbohydrate metabolism, the first indication of which is an increase in insulin levels for a same level of blood glucose, indicating an insulin resistance, which may eventually result in an impaired GTT and glucose disappearance rate. Consequently, the oestrogen component of oral contraceptive drugs is generally held responsible for the impairment of carbohydrate metabolism [9].

On the other hand, earlier studies [8] have shown that most oestrogenic substances ameliorate rather than aggravate diabetes.

Results reported by Beck $[1,2]$ suggest that at least in monkeys, some nortestosterone and progesterone derivatives (among which chlormadinone) used in contraceptive drugs, may be responsible for or at least contribute to the increased insulin response to intravenous glucose without impairment of glucose tolerance.

Our results clearly show that also in man the progestative may contribute to, or be responsible for, the increased insulin levels observed during treatment with contraceptive steroids. Glucose levels, on the other hand, were not significantly affected either by chlormadinone or by the other contraceptives tested, and, although slightly decreased both during chlormadinone and the sequential regimen, $K$ values did not show any statistically significant difference with the values obtained before treatment.

Unchanged glucose levels, and peripheral utilization $(K)$, at the expence of increased insulin levels, suggest the existence of a resistance to the hypoglycaemic effect of insulin. On the basis of the increased 
Table 1. Blood glucose, $K$ value, serum insulin "total insulin secretion", and insulin/glucose ratio, during $I . V . G T T$ prior to and post 12-13 months treatment with chlormadinone $(N=15$ unless otherwise noted)

\begin{tabular}{|c|c|c|c|c|c|c|c|c|}
\hline Measurement & $\begin{array}{l}\text { Time } \\
(\min )\end{array}$ & Pre & & Post & & Diff. & & $p$ \\
\hline Glucose & $\begin{array}{r}0 \\
3 \\
7 \\
10 \\
15 \\
30 \\
45 \\
60 \\
90\end{array}$ & $\begin{array}{l}0.88 \\
2.75 \\
2.46 \\
2.11 \\
1.75 \\
1.26 \\
0.90 \\
0.79 \\
0.77\end{array}$ & $\begin{array}{cc} \pm & 0.03 \\
\pm & 0.06 \\
\pm & 0.07 \\
\pm & 0.05 \\
\pm & 0.07 \\
\pm & 0.09 \\
\pm & 0.08 \\
\pm & 0.07 \\
\pm & 0.03\end{array}$ & $\begin{array}{r}0.93 \\
2.80 \\
* 2.45 \\
2.06 \\
* 1.78 \\
1.35 \\
1.05 \\
0.85 \\
0.78\end{array}$ & $\begin{array}{ll} \pm & 0.07 \\
\pm & 0.08 \\
\pm & 0.07 \\
\pm & 0.05 \\
\pm & 0.04 \\
\pm & 0.06 \\
\pm & 0.06 \\
\pm & 0.05 \\
\pm & 0.04\end{array}$ & $\begin{array}{r}0.05 \\
0.05 \\
*-0.03 \\
-0.05 \\
* 0.02 \\
0.09 \\
0.15 \\
0.06 \\
0.00\end{array}$ & $\begin{array}{ll} \pm & 0.06 \\
\pm & 0.07 \\
\pm & 0.08 \\
\pm & 0.06 \\
\pm & 0.08 \\
\pm & 0.08 \\
\pm & 0.09 \\
\pm & 0.06 \\
\pm & 0.04\end{array}$ & \\
\hline$K$ & & 2.04 & \pm 0.11 & 1.80 & $\pm \quad 0.14$ & -0.24 & \pm 0.17 & $>0.1$ \\
\hline Insulin & $\begin{array}{r}0 \\
3 \\
7 \\
10 \\
15 \\
30 \\
45 \\
60 \\
90\end{array}$ & $\begin{array}{r}14.0 \\
136.7 \\
91.7 \\
* 64.9 \\
50.2 \\
33.0 \\
* 21.6 \\
15.1 \\
13.2\end{array}$ & $\begin{array}{cc} \pm & 1.5 \\
\pm & 7.0 \\
\pm & 5.4 \\
\pm & 6.0 \\
\pm & 5.1 \\
\pm & 3.1 \\
\pm & 2.9 \\
\pm & 2.0 \\
\pm & 1.3\end{array}$ & $\begin{array}{r}18.2 \\
173.0 \\
125.3 \\
* 81.1 \\
80.5 \\
56.4 \\
* 39.6 \\
29.5 \\
16.6\end{array}$ & $\begin{array}{lr} \pm & 2.1 \\
\pm & 13.4 \\
\pm & 10.9 \\
\pm & 7.1 \\
\pm & 11.6 \\
\pm & 6.5 \\
\pm & 5.9 \\
\pm & 5.9 \\
\pm & 6.2 \\
\pm & 2.2\end{array}$ & $\begin{array}{r}4.3 \\
36.2 \\
33.6 \\
16.2 \\
30.3 \\
23.4 \\
18.0 \\
11.0 \\
3.5\end{array}$ & $\begin{array}{lr} \pm & 1.9 \\
\pm & 10.3 \\
\pm & 6.4 \\
\pm & 4.8 \\
\pm & 10.4 \\
\pm & 6.2 \\
\pm & 6.0 \\
\pm & 5.7 \\
\pm & 1.8\end{array}$ & $\begin{aligned} &< 0.05 \\
&< 0.01 \\
&<0.001 \\
&<0.01 \\
&<0.02 \\
&<0.01 \\
&<0.01 \\
&<0.05 \\
& 0.05\end{aligned}$ \\
\hline$\Sigma \mathrm{I}$ & & $* 426.5$ & \pm 19 & $* 602.0$ & \pm 37 & 175 & \pm 26 & 0.001 \\
\hline Insul/gluc. & $\begin{array}{r}0 \\
3 \\
7 \\
10 \\
15 \\
30 \\
45 \\
60 \\
90\end{array}$ & $\begin{array}{r}15.7 \\
49.9 \\
37.5 \\
* 31.1 \\
29.7 \\
27.9 \\
* 25.3 \\
19.3 \\
17.1\end{array}$ & 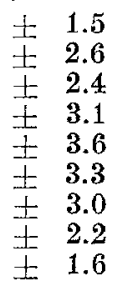 & $\begin{array}{r}21.0 \\
61.9 \\
* 51.1 \\
* 40.1 \\
* 46.5 \\
42.7 \\
* 42.8 \\
33.7 \\
21.9\end{array}$ & $\begin{array}{rr} \pm & 2.6 \\
\pm & 4.5 \\
\pm & 4.2 \\
\pm & 4.3 \\
\pm & 7.3 \\
\pm & 4.5 \\
\pm & 10.5 \\
\pm & 5.7 \\
\pm & 2.9\end{array}$ & $\begin{array}{r}5.3 \\
12.0 \\
14.0 \\
9.0 \\
17.6 \\
14.8 \\
17.6 \\
14.4 \\
4.7\end{array}$ & $\begin{array}{rr} \pm & 2.0 \\
\pm & 3.8 \\
\pm & 2.5 \\
\pm & 2.7 \\
\pm & 6.5 \\
\pm & 4.9 \\
\pm & 10.7 \\
\pm & 5.6 \\
\pm & 2.6\end{array}$ & $\begin{array}{l}<0.05 \\
<0.01 \\
<0.01 \\
<0.01 \\
<0.05 \\
<0.01 \\
>0.10 \\
<0.05 \\
>0.10\end{array}$ \\
\hline
\end{tabular}

Table 2. $K$ value, insulin levels, "total insulin secretion" and insulin/glucose ratios during I.V.GTT prior to and post Planovin therapy $(n=15)$

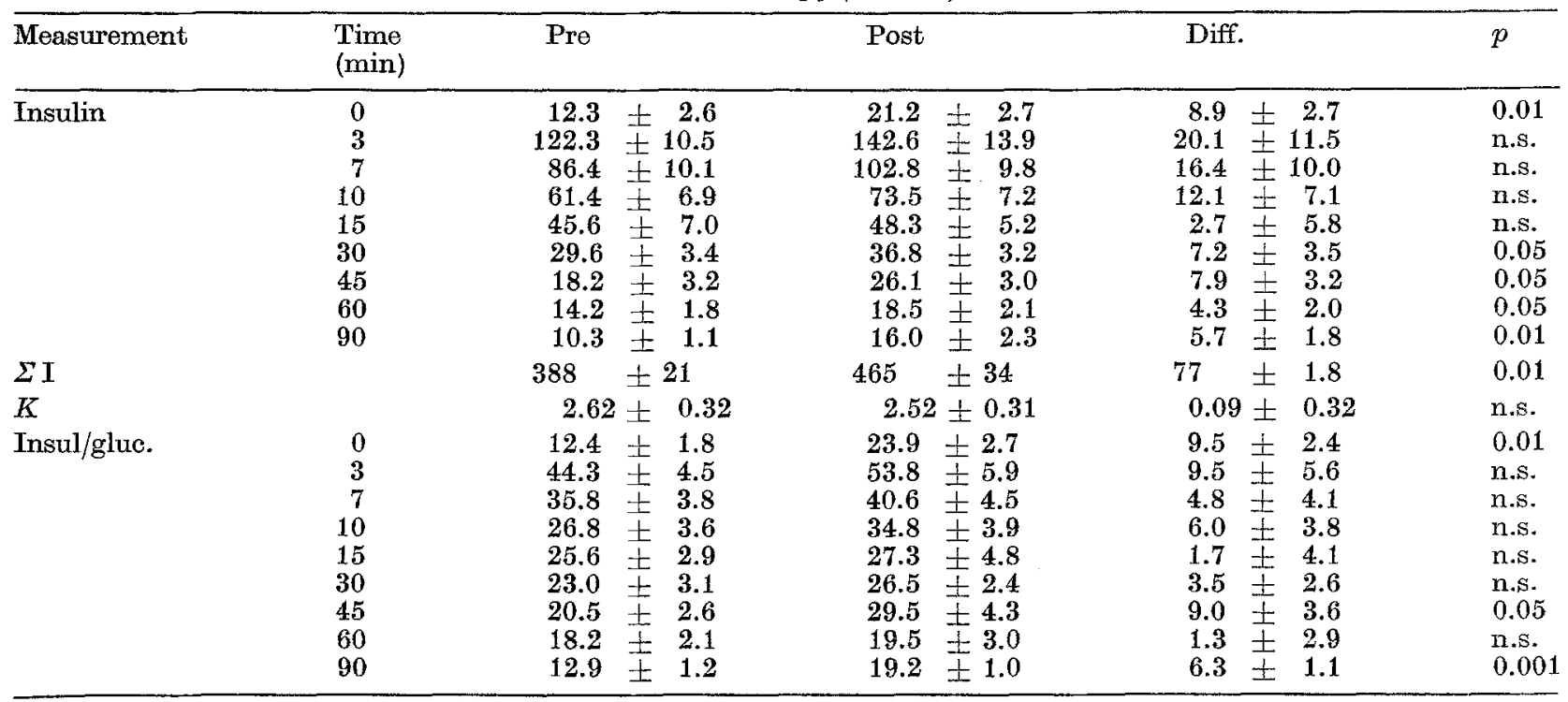

insulin levels and insulin/glucose ratios it appears that of the three contraceptive regimes tested, carbohydrate metabolism seems to be least affected by Pla. novin ${ }^{\circledR}$ (ethinylestradiol $50 \mu \mathrm{g}+4 \mathrm{mg}$ megestrol acetate) treatment, thus confirming the results obtained by Starup et al. [19].

Data concerning the effect of progestatives on car- bohydrate metabolism in man are rather contradictory. Indeed, Pýorola et al. [12] reported that a daily dose of $1 \mathrm{mg}$ of megestrol corrects the decrease in the intravenous glucose disappearance rate induced by ethinyloestradiol treatment, and Di Paola et al. [6] did not observe any impairment of the prednisolone-glucose tolerance test after $3-7$ months of treatment with 
Table 3. K value, Insulin levels, "total insulin secretion" and insulin/glucose ratios during $I . V . G T T$ prior and post sequential type contraception (C-C-2371-29) (Mestranol $100 \mu g$ and Mestranol $100 \mu g+$ Anageston $2 \mathrm{mg}$ ) (> $12 \mathrm{months}$

\begin{tabular}{|c|c|c|c|c|c|c|c|c|}
\hline Measurement & $\begin{array}{l}\text { Time } \\
\text { (min) }\end{array}$ & $\overline{\text { Pre }}$ & & Post & & Diff. & & $p$ \\
\hline Insulin & $\begin{array}{r}0 \\
3 \\
7 \\
10 \\
15 \\
30 \\
45 \\
60 \\
90\end{array}$ & $\begin{array}{r}11.8 \\
118.2 \\
84.1 \\
64.6 \\
46.7 \\
30.2 \\
18.4 \\
13.0 \\
10.3\end{array}$ & $\begin{array}{ll} \pm & 1.8 \\
\pm & 8.2 \\
\pm & 6.5 \\
\pm & 6.5 \\
\pm & 6.8 \\
\pm & 3.2 \\
\pm & 2.6 \\
\pm & 2.1 \\
\pm & 1.5\end{array}$ & $\begin{array}{r}14.9 \\
135.7 \\
98.3 \\
83.0 \\
68.2 \\
41.6 \\
32.1 \\
23.8 \\
16.5\end{array}$ & $\begin{array}{lr} \pm & 1.6 \\
\pm & 9.5 \\
\pm & 11.3 \\
\pm & 7.8 \\
\pm & 6.5 \\
\pm & 4.5 \\
\pm & 6.5 \\
\pm & 2.4 \\
\pm & 1.8\end{array}$ & $\begin{array}{l}+3.1 \\
+17.5 \\
+14.2 \\
+18.4 \\
+18 \\
+21.5 \\
+11.4 \\
+13.7 \\
+10.8 \\
+6.2 \\
+\end{array}$ & 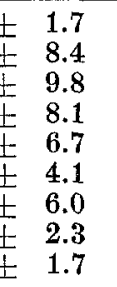 & $\begin{array}{l}\text { n.s. } \\
0.05 \\
\text { n.s. } \\
0.05 \\
0.01 \\
0.02 \\
0.05 \\
0.001 \\
0.01\end{array}$ \\
\hline$\Sigma \mathrm{I}$ & & 386 & \pm 17 & 499 & \pm 41 & +113 & \pm 32 & 0.01 \\
\hline$K$ & & 2.82 & \pm 0.31 & 2.10 & \pm 0.33 & $-0.72 \pm$ & \pm 0.31 & 0.05 \\
\hline Insul/gluc. & $\begin{array}{r}0 \\
3 \\
7 \\
10 \\
15 \\
30 \\
45 \\
60 \\
90 \\
\end{array}$ & $\begin{array}{l}12.2 \\
45.8 \\
36.2 \\
28.0 \\
25.2 \\
25.1 \\
23.6 \\
17.5 \\
14.1 \\
\end{array}$ & $\begin{array}{cc} \pm & 1.6 \\
\pm & 3.9 \\
\pm & 3.4 \\
\pm & 2.8 \\
\pm & 3.0 \\
\pm & 2.8 \\
\pm & 2.6 \\
\pm & 2.2 \\
\pm & 2.8\end{array}$ & $\begin{array}{l}17.8 \\
51.1 \\
43.0 \\
38.8 \\
36.3 \\
31.6 \\
30.8 \\
27.2 \\
21.7 \\
\end{array}$ & $\begin{array}{cc} \pm & 2.1 \\
\pm & 6.0 \\
\pm & 6.2 \\
\pm & 5.2 \\
\pm & 4.5 \\
\pm & 4.2 \\
\pm & 4.8 \\
\pm & 3.2 \\
\pm & 4.3\end{array}$ & $\begin{array}{r}+5.6 \\
+5.3 \\
+\quad 5.8 \\
+\quad 6.8 \\
+10.8 \\
+11.1 \\
+6.5 \\
+7.2 \\
+ \\
+9.7 \\
+7.6 \\
+\end{array}$ & $\begin{array}{ll} \pm & 2.1 \\
\pm & 4.3 \\
\pm & 5.1 \\
\pm & 4.2 \\
\pm & 4.0 \\
\pm & 3.5 \\
\pm & 3.2 \\
\pm & 3.0 \\
\pm & 3.6 \\
\end{array}$ & $\begin{array}{l}0.05 \\
\text { n.s. } \\
\text { n.s. } \\
0.05 \\
0.05 \\
\text { n.s. } \\
0.05 \\
0.01 \\
0.05 \\
\end{array}$ \\
\hline
\end{tabular}

norethisterone acetate $5 \mathrm{mg}$ daily; insulin levels were however not studied.

Schreibman and Hurwitz [14], on the other hand, observed a deterioration of the OGTT in $64 \%$ of the patients to whom Delatutin (hydroxyprogesterone caproate) had been administered, whereas Benjamin \& Casper [4], using the same product, have reported an improvement of the OGTT in half of their patients. Several authors have concluded that at the same dosage of mestranol, the diabetogenic effect of a contraceptive pill may be different, the action depending upon the type and dose of the progestative incorporated. Thus it has been reported that glucose intolerance develops much more frequently in women taking norethynodrel than in those employing ethynodiol or sequential drugs [2].

While we were preparing this paper, Larsson-Cohn et al. [11] reported that continuous treatment with either $0.5 \mathrm{mg}$ norethindrone or $0.5 \mathrm{mg}$ of chlormadinone did not induce any change in fasting blood glucose, $K$ value or insulin response to IVGTT. Although our experimental design is very similar to that of these authors, our results concerning the insulin response to IVGTT chlormadinone are clearly discordant; the reasons for this discrepancy are not clear but could be related to the selection of the subjects or to methodological differences.

Whereas it is often assumed that sequential type contraceptives cause fewer alterations in carbohydrate metabolism than combination type contraceptives [11], we observed more important alterations in glucose metabolism during sequential treatment with Mestranol $100 \mu \mathrm{g}$ and Anagestonacetate $2 \mathrm{mg}$, than during treatment with a combination type contraceptive containing megestrolacetate $4 \mathrm{mg}$ and $0.05 \mathrm{mg}$ of ethinylestradiol. Yen and Vela [25] observed the same in- crease in plasma insulin and growth hormone levels in women receiving either a sequential type contraceptive (with dimethisterone) or a combination (with ethynodiol acetate).

Elevated plasma insulin levels after six months of sequential contraception with $2 \mathrm{mg}$ chlormadinon acetate and $80 \mu \mathrm{g}$ mestranol, have also been reported by Spellacy et al. [17] although after one year of treatment, normal insulin and glucose levels were observed [18].

It seems therefore that with respect to the influence of contraceptive drugs on carbohydrate metabolism, no generalizations claiming the superiority of either the luteal supplementation, the sequential, or combination type of oral contraception, should be made, but that whatever regimen used, the type and quantity of both oestrogen and progestogen used are the determining factors. Although results reported in the literature are often discordant, most studies seem to indicate that of the different oestrogens used in contraception, mainly mestranol $[1,6,10]$ affects adversely carbohydrate metabolism, ethinyloestradiol producing less readily impairment of carbohydrate me. tabolism. As far as progestogens are concerned, from available data it would appear that although many progestogens may cause insulin resistance, megestrol. acetate $[19,12$ and this paper] and probably ethynodioldiacetate $[1,2]$ (although for the latter the evidence is not so strong), probably do not have any ad. verse effect on carbohydrate metabolism.

The mechanism of impairment of carbohydrate metabolism by oral contraceptive drugs is still controversial. Since normal glucose assimilation and blood glucose levels are maintained at the expense of increased insulin levels, resulting in increased insulin/glucose ratios, this suggests an inhibition of the peripheral 
utilization of glucose. It has been suggested that elevated plasma cortisol $[22,23]$ or growth hormone levels $[25,20]$, or impairment of liver function [9, 22], might be responsible for this inhibition. Elevated plasma cortisol levels are observed with oral contraceptives containing oestrogens but we did not observe any influence of $0.5 \mathrm{mg}$ chlormadinone on the total plasma cortisol levels; although the free non-protein bound cortisol fraction has not been determined, it seems at present improbable that the insulinogenic effect of chlormadinone would be mediated via an increase in free cortisol levels. Since growth hormone is diabetogenic and since increased growth hormone levels have been reported after treatment with oestrogen containing contraceptives $[25,16]$, it has been suggested that the impairment of carbohydrate metabolism might be mediated by increased growth hormone secretion; after progestin treatment however Yen and Vela [25] observed normal growth hormone levels, and Beck [3] observed in fact a decrease in H.G.H. levels after 6 months of chlormadinone treatment: it seems improbable therefore that the hyperinsulinism observed during chlormadinone treatment is dependent upon growth hormone secretion. Finally, by routine tests we did not observe any impairment of liver function with any of the drugs studied, although it is possible that more refined tests might reveal alterations in liver function [22]. It is obvious that none of the hypotheses so far proposed provide us with a satisfactory explanation for the inhibition of the peripheral utilization of glucose and insulin resistance observed during the treatment with contraceptive pills.

To sum up: our results indicate that increased plasma insulin levels with normal glucose levels after IVGTT may be observed during luteal supplementation as well as in the course of treatments using either sequential or combination contraceptive regimens. More than the type of contraceptive regimen used, the type and quantity of both the oestrogen and the progestogen determine the eventual influence of oral contraceptives or carbohydrate metabolism.

Acknowledgements. We wish to thank Syntex Research for the gift of Chormadinone ${ }^{\circledR}$; Novo Industri AGS for the gift of Planovin ${ }^{\circledR}$ and Ortho Pharmaceuticals for the gift of ORF $1658 \mathrm{~K}$.

These studies were supported by a research grant from the Synthex Do and by grant no 1170 of the F.W.G.O. Belgium.

\section{References}

1. Beck, P.: Effects of gonadal hormones and contraceptive steroids on glucose and insulin metabolism. In: Salhanick, H.R., Kipnis, D.M., and Van de Wiele, R.L., Metabolic effects of gonadal hormones and contraceptive steroids, p. 67. New York. Plenum Press 1969.

2. Beck, P.: Progestin enhancement of the plasma insulin response to glucose in Rhesus monkeys. Diabetes 18, 146-152 (1969).

3. - Personal communication.

4. Benjamin, F., Casper, D.J.: Alterations in carbohydrate metabolism induced by progesterone in cases of endometrial carcinoma and hyperplasia. Amer. J. Obstet. Gynec. 94, 991 - 996 (1966).

5. Conrad, V.: Mesure de l'assimilation du glucose. Acta gastro-ent, belg. 18, $655-705$ (1955).

6. Di Paola, G., Puchulu, F., Robin, M., Nicholson, R., Mart, M.: Oral contraceptives and carbohydrate metabolism. Amer. J. Obstet. Gynec. 101, 206-216 (1968).

7. Dubowski, K.M.: An o-Toluidine method for body fluid glucose determination. Clin. Chem. 8, 215-235 (1962).

8. Houssay, B.A., Foglia, V.G., Rodriguez, R.R.: Production or prevention of some types of experimental diabetes by estrogens or corticosteroids. Acta endocr. 17, 146-164 (1954).

9. Javier, Z., Gershberg, H., Hulse, M.: Ovulatory supressants, estrogens and carbohydrate metabolism. Metabolism 17, 443-456 (1968)

10. - Gershberg, H.: Synergetic effect of estrogen on the cortisone glucose tolerance test. Clin. Res. Proc. 12, 458 (1964).

11. Larsson-Cohn, U., Tengström, B., Wide, L.: Glucose tolerance and insulin response during daily continuous lowdose oral contraceptive treatment. Acta endocr. 62, 242-250 (1969).

12. Pyorola, K., Pyorola, T., Lampinen, V.: Sequential oral contraceptive treatment and intravenous glucose tolerance. Lancet $1967 \mathrm{II}, 776-777$.

13. Sargent, D.W.: Weight - height relationship of young men and women. Amer. J. Clin. Nutr. 13, $318-325$ (1963).

14. Schreibman, P.H., Hurwitz, D.: Alterations in carbohydrate and lipid metabolism by a progestin. Diabetes 17, $341-342(1968)$.

15. Spellacy, W.N.: A review of carbohydrate metabolism and the oral contraceptives. Amer. J. Obstet. Gynec. 104, 448-460 (1969).

16. - Carlson, K.L.: Plasma insulin and blood glucose levels in patients taking oral contraceptives. Amer. J. Obstet. Gynec. 95, 474-478 (1966).

17. - - Shade, S.L.: Effect of a sequential oral contraceptive on plasma insulin and blood glucose levels after 6 months treatment. Amer. J. Obstet. Gynec. 101, $672-676$ (1968).

18. - Buhi, W.C., Bendell, R.P.: Insulin and glucose studies after one year treatment with a sequential type oral contraceptive. Obstet. and Gynec. 33, 800803 (1969).

19. Starup, J., Date, J., Deckert, T.: Serum insulin and intravenous glucose tolerance in oral contraception. Acta endocr. 58, 537-544 (1968).

20. Steiner, H.: Wachstumhormon bei peroraler Antikonzeptionsbehandlung. Schweiz. med. Wschr. 99, 11151118 (1969).

21. Waine, H., Frieden, E.H., Caplan, H.I., Cole, R.: Metabolic effects of Enovid in rheumatoid patients. Arthr. and Rheum. 6, 796-797 (1963).

22. Wynn, V., Doar, J.W.H. : Some effects of oral contraceptives on carbohydrate metabolism. Lancet 1966 II, $715-719$.

23. - - Some effects of oral contraceptives on carbohydrate metabolism. Lancet 1969 II, $761-765$.

24. Yalow, R.S., Berson, S.A.: Immunoassay of endogenous plasma insulin in man. J. clin. Invest. 39, 1157-1175. (1960).

25. Yen, S.S.C., Vela, P.: Effects of contraceptive steroids on carbohydrate metabolism. J. clin. Endocr. 28, 1564- 1570 (1968).

Prof. Dr. A. Vermeulen

Dept. of Endocrinology and Metabolism Akademisch Ziekenhuis

State University

Ghent, Belgium - De Pintelaan 115 